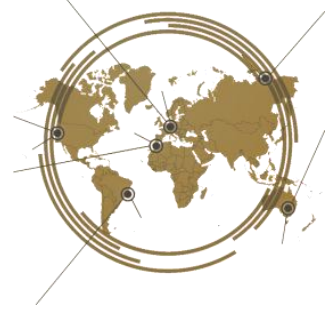

\title{
Professional identity construction of EFL teachers as autonomous learners
}

\author{
Sri Rachmajanti, ${ }^{1}$ Gunadi Harry Sulistyo ${ }^{1}{ }_{1}^{1}$ Fika Megawati, ${ }^{2}$ Ayu Alif Nur Maharani Akbar ${ }^{1}$ \\ ${ }^{1}$ English Department, Universitas Negeri Malang, Indonesia, \\ ${ }^{2}$ English Language Education, Universitas Muhammadiyah Sidoarjo, Indonesia
}

Teacher Professional Development (TPD) is exponential for English teachers to the success of teaching and learning process in the classroom. Teachers with professional identity are deemed to have good quality in teaching. As stipulated by Rodgers \& Scott (2008) teachers with professional identity are deemed to have good quality in teaching. The efforts to do this can be accomplished through such ways as participating in conferences, seminars, workshops, and non-degree training, or even pursuing their further studies to master' $s$ degree and doctorate program. Also, they can conduct research and publish articles. This article is intended to provide evidence how novice, mid-career, and senior EFL teachers construct their identity professionally and autonomously. To arrive at the purpose of the study, an explorative survey was carried out to $129 \mathrm{EFL}$ teachers throughout the Province of East Java via online questionnaire with 37 close-ended items. The findings revealed that (1) EFL teachers, be they junior, mid-career or senior ones involved in the present study, have tried to professionalize themselves via a number of corridors from self-directed ones to the ones imposed by other professional development providers; (2) they have various professional and pedagogical knowledge and skills related to becoming professional EFL teachers. In conclusion, EFL novice, mid-career or senior teachers have manifested their professional identity with a number of corridors as professional autonomous learners.

Keywords: professional identity, EFL teachers, autonomous learners

OPEN ACCESS

ISSN 25033492 (online)

${ }^{*}$ Correspondence:

Gunadi Harry Sulistyo

gunadi.hs@um.ac.id

Received: 25th October 2021 Accepted: 15th November 2021

Published: 15th November 2021

Citation:

Rachmajanti, S. Sulistyo, G.H,. Megawati, F. and Akbar, A.A.N.M,.

(2021). Professional identity construction of EFL teachers as autonomous learners.

J. Eng. Educ. Society. 6:2. doi:10.21070/jees.v6i2.1646

\section{INTRODUCTION}

One of the factors contributing to the success of teaching and learning process is how teachers develop themselves through teacher professional development (TPD). TPD is designed to help teachers develop their teaching skills and learners to achieve their meaningful learning. The activities of TPD teachers can do vary. According to Davidson et.al (2012), teachers take part in conferences, seminars, workshops, and non-degree training. They can also pursue their further studies to master's degree and doctorate program. In addition, they can conduct research and publish articles they have written. Research has shown that TPD is significantly helpful in developing the quality of teachers' career in the context of teaching and learners learning outcomes in the classroom. A study conducted by Guskey (2003) verifies that TPD shows a positive impact on both teachers' credentials and students' achievements. Wayne et. al (2008) also state that PD which is carried out intensively can improve teacher knowledge, classroom teaching, and student achievement. 
For the last two decades, however, TPD has been linked to the importance of professional identity of teachers. Professional identity is about how teachers see, perceive, or define themselves and others in the process of being professional. To Lace (2014), professional identity can be understood as teacher's personality, profession, and ambition. Similarly, Ivanova \& Skara (2016) opine that professional identity is attributed to personal, social, cultural, political, professional, and global matters. In more detailed description, professional identity can be elaborated within four characteristics: (1) teacher identity is built by varied contexts: social, culture, politics, and history; (2) teacher identity involves interpersonal relationship; (3) teacher identity is dynamic; and (4) teacher identity should be constructed and reconstructed (Rodgers \& Scott, 2008).Teachers with professional identity are deemed to have good quality in teaching. As said by Rodgers \& Scott (2008), professional identity is the core element in relation to teaching as a profession, and therefore, teachers having strong professional identity will be an effective teacher Palmer (1998). Several scholars (for instance Joseph \& Heading, 2010; Stets \& Burke, 2000; Wenger, 1998; Sparks $\&$ Shepherd, 1992) also argue that teachers who understand themselves and their roles of teaching and learning will affect students' learning experiences and environment.

Research on professional identity has also been executed in different contexts. According to Beijaard, Meijer, \& Verloop (2004), there are three categories of research on professional identity already carried out: (1) teachers' professional identity formation; (2) identification of characteristics of teachers' professional identity; and (3) representation of teachers' professional identity in the form of stories. Similarly, Djoub (2018) has also three categories of research on professional identity: (1) the construction and development of teachers' professional identity; (2) teachers' perceptions of their professional roles; and (3) the relationships between teachers' perceptions of their roles and their self-image.

However, none or little of the existing research has been conducted focusing on EFL how English teachers of junior high schools construct their professional identity. Besides, the existing research does not have sufficient data on professional identity from seniority of EFL teachers: novice, mid-career, and senior that can be used to compare and contrast. In more specific, there is lack of information about how EFL teachers from those three ranks professionalize themselves during their teaching career, view themselves at becoming professional in their career, and learn the knowledge and skills they have achieved upon becoming professional as EFL teachers. Considering these, therefore there is a need to explore further how English teachers of junior high schools construct their professional identity. The research questions cover:

1. How do novice, mid-career, and senior EFL teachers professionalize themselves during their teaching career?

2. What knowledge and skills do novice, mid-career, and senior EFL teachers have related to becoming professional as EFL teachers?

\section{METHODS}

As the present study seeks to uncover their struggle as lived experiences on professionalizing themselves as novice, mid-career, and senior EFL teachers, an explorative survey was adopted. The study involved 129 EFL teachers of different ranks in the lower secondary level of education in East Java. The purpose is more on identifying the variability and the construction of this variability by different aspects that delineate the EFL professionalism, rather than to identify the singularity of the nature of constructing professionalism in EFL context (Fox, 2006).

The main instrument employed to collect the data was a set of questionnaires, comprising aspects pertaining to demo and biographic data, as well the variables under interest. The scope of the areas of professional identity construction of EFL teachers as autonomous learners incorporated updated knowledge and skills, scholarly activities, networking, selfassessment on the level of professionalism, identifying aspects making them professional, lesson planning, conducting research and publishing journal articles.

Prior to its use, the questionnaire was tried out to a number of 30 teachers of English. These teachers shared almost the same characteristics of the target population in that they consisted of teachers with different teaching experiences at different levels of education. The trial aims to see the clarity of the instruction, the validity of items, the amount of time for completing the questionnaire, and the reliability of the questionnaires. Upon the informal trial, several points of the questionnaires were revised, then set in a Google form, and ultimately distributed online through teachers' WA groups.

After scrutinizing the responses, the data were grouped according to the attribute classification of the respondents as displayed in Table 1.

TABLE 1 The Criteria for Setting up the Three Groups of EFL Teachers

\begin{tabular}{cccc}
\hline $\begin{array}{c}\text { Aspect of } \\
\text { the Criteria }\end{array}$ & Novice & Mid-Career & Senior \\
$\begin{array}{c}\text { Teaching } \\
\text { experiences }\end{array}$ & $\begin{array}{c}0-5 \\
\text { years }\end{array}$ & $6-10$ years & 0 years \\
\hline
\end{tabular}

Based on the criteria, the number of the EFL teachers in each category can be identified as follows: 37 novices, 44 mid-career and 48 senior. After the respondents are identified according to their classification, the responses of the respondents in each classification are further analyzed against the variable in each research question.

\section{RESULTS AND DISCUSSION}

\section{Teachers' Attempts to Professionalize Themselves}

Teachers' attempts to improve their professionalism are classified by such ways as improving their English, joining workshops on teaching methods, on producing both conventional and ICT-based instructional media, and on 
conducting research, performing research, teachers' joining relevant online courses on instructional methods, reading relevant sources in the Internet, joining online discussions with colleagues, having offline discussion with colleagues as well as experts, applying flipped and blended learning in the classroom, writing best practice in articles, performing on-line testing, making teaching kits of their own, joining professional organizations, research experiences, publication experiences, and winning competitions. Figure 1 elaborates the teachers' effort to improve their competences in English.

FIGURE 1 | Teachers' Attempts to Improve their Competences in English

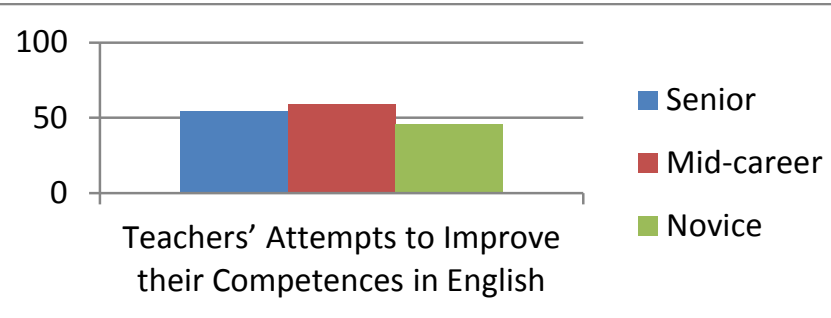

It was evident in Figure 1 that the majority of teachers in senior and mid-career groups (more than $50 \%$ of teachers in both groups) were committed to improve their English competences. Meanwhile, the percentage of teachers in novice group in improving their English competences was the lowest among the others. As the attempts to improve teachers' professionalism, teachers may join pedagogical workshops to keep updated with the current trends in ELT as seen in Figure 2.

FIGURE 2 | Teachers' Attempts to Join Various Workshops

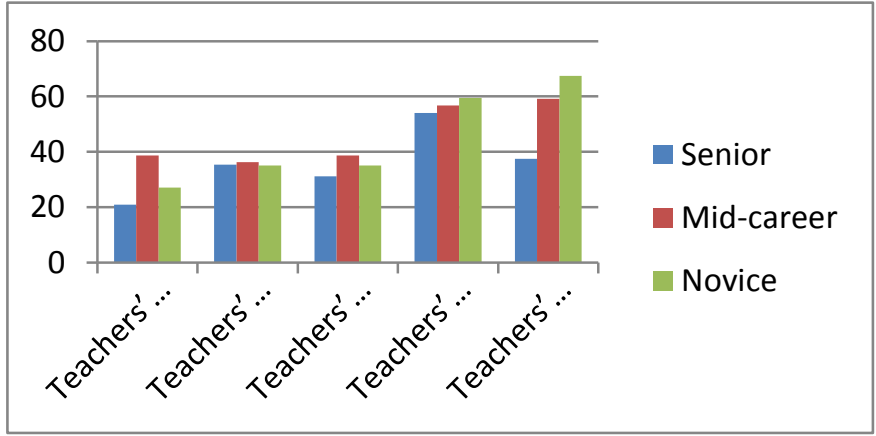

Figure 2 reflected that teachers in the three groups were more triggered to join workshops on ICT-based teaching platforms compared to other themes. However, there was no significant discrepancy on teachers' attempts in joining workshops in developing conventional and ICT-based instructional media. In addition, teachers in mid-career and novice groups showed higher interest on classroom research workshops. Regarding to teachers' attempt to perform classroom action research, the majority of teachers in the three groups had conducted CAR at least once. The midcareer group and the novice group showed higher CAR participation than the senior group. However, compared to the other two groups, the senior group reflected the highest participation in writing their best practice into articles. What about learning from any relevant resources then? It turned out that the senior and the mid-career groups reflected higher attempts to learn from both relevant online courses and other sources in internet. Less than $25 \%$ of the novice teachers were willing to learn from internet-based or online sources. Figure 3 deals with learning through discussion.

FIGURE 3 | Teachers' Attempts to Discuss with Colleagues and Experts

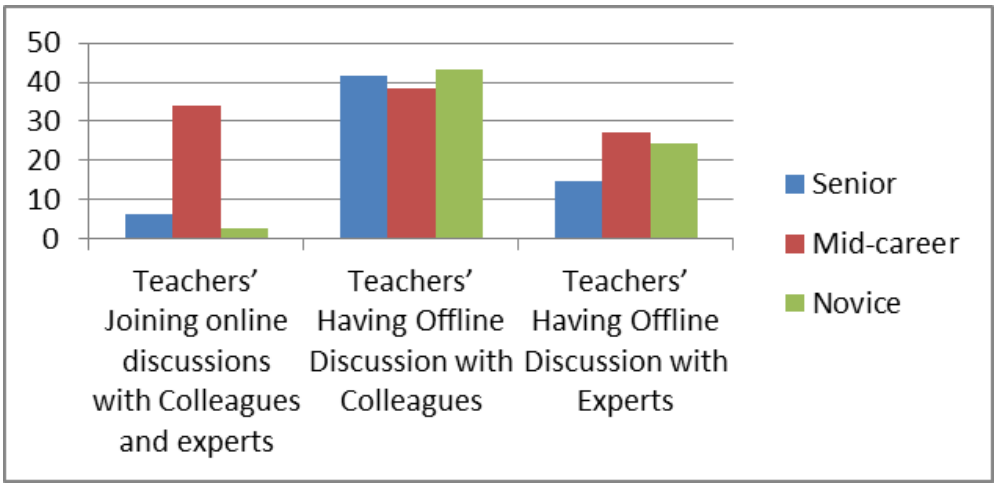

As invented in Figure 3, having offline discussion with colleagues seemed to be more comfortable for teachers in the senior, mid-career, and novice groups. However, the mid-career and novice groups preferred to have an offline discussion to discuss their pedagogical problems with experts. The mid-career group was the only group who was more comfortable to have an online discussion with the experts. What about the instructional process?

FIGURE 4 | Teachers' Attempts to Integrate Technology and Teaching Learning Activities

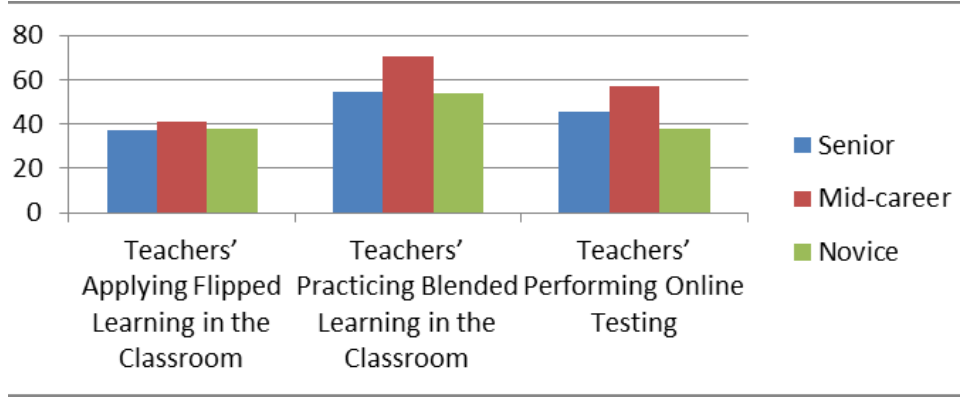

The summary of Figure 4 indicated that the mid-career group was the most frequent group in conducting flipped learning, blended learning, and online testing than the other two groups. The senior and the novice groups reflected the same percentage in the implementation of flipped learning and blended learning. However, the novice indicated the lowest percentage in performing the online testing. Whereas, in using media, it revealed that less than $25 \%$ of teachers in the mid-career and novice groups made their own teaching tools, and less than $10 \%$ of the senior group made their own teaching tools. In other words, media making was not of 
their priority in the instructional process. Then, did they join any professional organization to improve their professionalism? As verified in this study, more than $30 \%$ of teachers in mid-career group joined professional organizations. In contrary, teachers in senior and novice groups showed lower participation in professional organization (18.8\% of the senior and $21.6 \%$ of the junior). Figure 5 discovers other attempts.

FIGURE 5 | Teachers' Experience in Writing Publications and Winning Competition

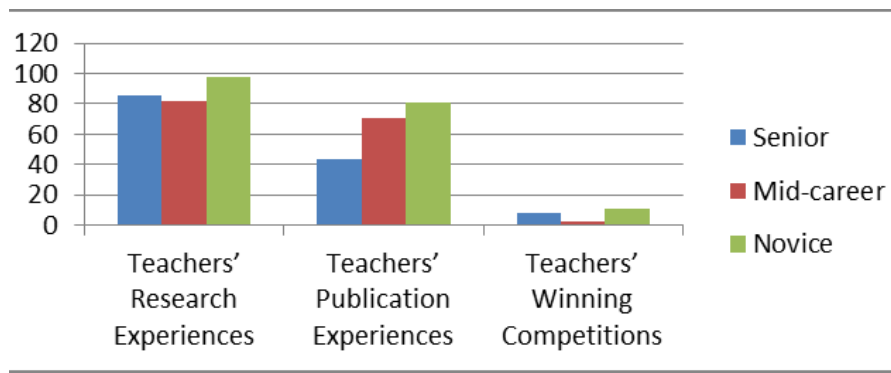

As observed in Figure 5, almost all teachers (more than $80 \%$ ) in the three groups had the experiences in conducting research. The majority of teachers in the middle and novice groups (more than 60\%) also had published their articles. However, almost all teachers in the three groups had never won any competition in their career.

\section{What Skills and Knowledge Teachers Have Learned?}

This section presents the result of analysis on what the teachers of the three categories have learned referring to the problems in understanding basic competences, abilities to formulate indicators of achievement competence, ability to formulate indicators of graduate competences, problems in determining the scope of instructional materials relevant to learning indicators, abilities to select appropriate teaching techniques, to use relevant learning resources, to use relevant instructional media appropriately, to develop relevant assessment tools and innovative teaching strategies, to develop a lesson plan, to conduct classroom action research and to write articles for journal publication. Figure $\underline{6}$ presents pedagogical problems faced by teachers.

FIGURE 6 | Pedagogical Problems Faced by Teachers

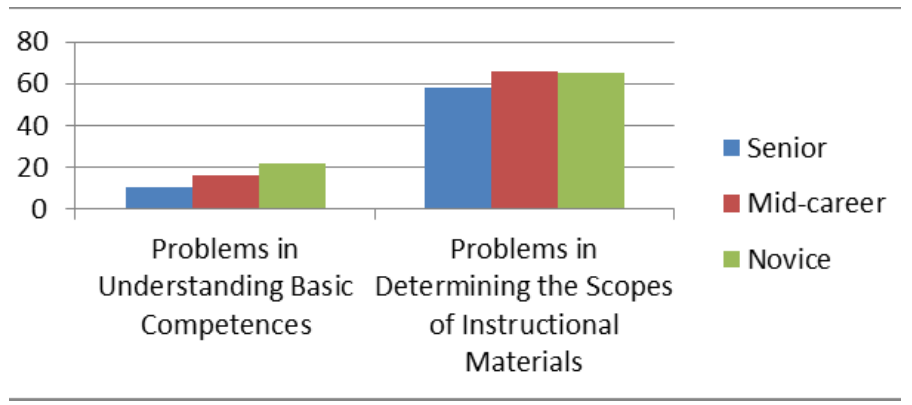

Figure 6 indicated that most teachers in the three groups did not face any problems in understanding basic competences stipulated in the content of Curriculum 2013. However, teachers in the novice group seemed to have more problems in understanding basic competences than those in the senior and mid-career groups. Determining the instructional media tended to be more problematic for the majority of teachers in the three groups.

FIGURE 7 | Teachers' Confidences on their Pedagogical Ability

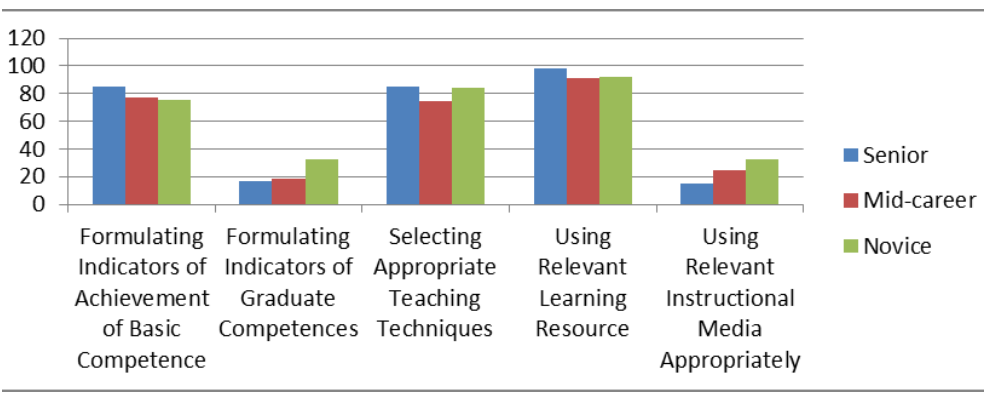

As invented in Figure 7, the majority of teacher in the three groups were confident with their ability in formulating indicators of basic competences, selecting appropriate teaching techniques, and using relevant learning resources. However, formulating indicators for graduate competences and using instructional media appropriately tended to be the most problematic aspects for the teachers in senior, midcareer, and junior groups.

FIGURE 8 | Teachers' Confidences on their Pedagogical Ability

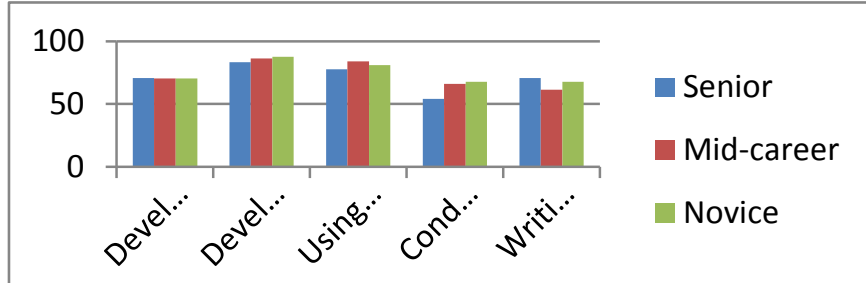

The summary of Figure 8 indicated teachers' confidences on their ability in developing relevant assessment tools, developing lesson plans, using innovative teaching strategies, conducting CAR, and writing articles for publication. The majority of teachers in the three groups (more than 50\%) were convinced with their ability in those five aspects. However, regarding to the teachers' ability in conducting CAR, the senior showed the lowest percentage (54.2\%) compared to the two.

Based on the aforementioned findings, it is evident that on their level of professionalism the three-group teachers claim to be professional although the level of professionalism and the number of the teachers in the level differ markedly. However, the majority of them state to be in the mid-level of being professional. This phenomenon is observable across the subjects' seniority: novice teachers, 
mid-career teachers and senior teachers. Only few claim to be in low and very low levels of professionalism. Meanwhile, those who claim to be highly professional constitute about (49 teachers) or one thirds (38\%) of the accessible population of the present study (129 teachers).

The findings above mostly accord the norms stipulated by the government about professional teachers as outlined in Law of the Republic of Indonesia Number 14, 2005 about teachers and college/university lecturers' rights and responsibilities and the Regulation of the Ministry of National Education Number 16, 2007 on the Standards of Academic Qualifications and Teacher $\mathrm{s}^{\text {ee }}$ Professional Competences. In addition, the findings above also echo the requirements of teachers in order to be regarded professional as set up in other countries like Ireland, Australia, and the United Kingdom. For example, the Republic of Ireland has a Code of Professional Conduct (Teaching Council, 2012); Australia has Professional Standards for Teachers, and the Department of Education, the UK has set up Teachers' Standards (Department of Education, 2011). In other words, the criteria viewed by the teachers in the present study are considered to be universal ones in that there are rules for teachers to observe in order for them to be professional. This is supported by some studies (Tichenor and Tichenor, 2005) revealing that teachers' professionalism is manifested in a number of ways. In addition, becoming professional teachers covers not only attitudes but also behaviors. A study by Van der Klink et. al (2017) disclosed that in their early profession, teachers were concerned more on how to survive. Later, however, they put more attention to creating the image of being professional in which they were concerned with the welfare of their students' learning as individuals. Becoming professional to them means they needed to be engaged in a number of professional activities in order for them to develop. Hilton, Flores, \& Niklasson, (2013) found out that teachers set up their views as ways for them to be considered professional that will lead to good quality. This is one of ways for them to professionalize themselves apart from the standards set up by the government. In brief, teachers had similar concerns on the notion of professionalism.

It is also observed that teachers across seniority share almost similar levels of achievement in these areas described previously. This means that no matter how senior or novice they are, they claim they have learned something important pertaining to their different professional status. In most areas, they essentially learn aspects required to be performed by teachers in their job. In other words, professional teachers no matter what level they hold have learned something useful from their practice in implementing principles they view essential aspects of professionalism. This has also been proven by some studies claiming that teachers' professional development activities they attempted are linked significantly to their teaching practices. The teachers changed in the teaching practice when the teacher utilized innovative modes of teaching and methodology in the classroom. In addition, professional development affected their performance in terms of not only their amplified selfassurance and upgraded content knowledge but also improvement in their use of instructional approaches and the importance of having professional partnerships. (Zaidi, Khan, \& Khan, 2018; Piedrahíta, 2018; Kekana, \& Gaigher, 2018; and Alghamdi \& Sihes, 2015).

Conceptually, professional development aims at facilitating teachers to develop their teaching skills from which their learners can gain their meaningful learning. The form of professional development, according to Davidson et. al (2012) can take a varied form, from joining in conferences, seminars, workshops, non-degree training, or even pursuing further studies. The findings of the present study reflect a study by Guskey (2003) showing that professional development positively impacts not only teachers $^{\text {ee }}$ qualifications but also their students ${ }^{\text {ee }}$ learning achievements. In addition, Wayne et. al (2008) are also of the view that intensive professional development program can improve teacher knowledge, classroom teaching, and student achievement.

\section{CONCLUSION}

It can be concluded that EFL teachers, be they novice, midcareer or senior ones involved in the present study, have tried to professionalize themselves. They take a number of corridors to make them professional from self-directed ones to the ones imposed or provided by other professional development providers. In addition, to them, being professional means that teachers need to meet 4 essential aspects in order for them to be considered professional. These 4 aspects cover essential characters that an individual teacher must have, personal attributes that are related to their pedagogic competences, their view regarding the importance of personal development, and classroom conducts a professional teacher may do.

Seeing themselves as a professional albeit with different levels of professionalism, the subjects of the present study claim that they learn something useful from the view they hold. The lesson learned includes an array of competences from the ability to understand basic competences, to elaborate instructional materials related to the basic competences, to select relevant learning experiences for their students, to their ability to conduct classroom research and to write an article for publication.

It is then recommended that future researchers collect further data on the part of students for reflection so that the study will be more comprehensive and beneficial particularly for teachers' professional identity. It is likely school principals and stakeholders are also involved in future 
research data collection to provide more holistic data on teachers' professional identity. Moreover, classroom observation is also recommended for future researcher to triangulate teachers' claim on their professional identity and the real practices in the classroom.

\section{ACKNOWLEDGEMENTS}

Special gratitude is addressed to all teachers being engaged in our study.

\section{REFERENCES}

Alghamdi, A.K.H. \& Sihes, A.J. (2015). Effect of professional development on classroom practices in some selected Saudi Universities. International Journal of Higher Education. 5(1), 152-159.

Australia Institute for Teaching and School Leadership/AITSL. (2011). Professional standards for teachers. Melbourne: Author. Available from http://www.aitsl.edu.au/australian-professionalstandards for teachers (accessed on March 25, 2019).

Beijaard, D. Meijer, P. C. \& Verloop, N. (2004). Reconsidering research on teachers professional identity. Teaching and Teacher Education, 20(2), 107-128.

Davidson, G., Dunlop, F., Soriano, D. H., Kennedy, L., \& Phillips, T. (2012). Goingforward: Continuing professional development for English language teachers in the UK. UK: British Council.

Department of Education. (2011). Teachers' standards. London: Author. Available from http://www.gov.uk//government/publications/teacher s-standards (accessed on March 25, 2019)

Djoub, Z. (2018). Exploring teachers' identity: Reflections and implications. Arab World English Journal (AWEJ). 9.

Fox, N. (2006). Using interviews in a research project. The NIHR RDS for the East Mid- careerlands / Yorkshire $\&$ the Humber.

Hilton, G., Flores,M.A., \& Niklasson, L. (2013). Teacher quality, professionalism and professional development: Findings from a European project. Teacher Development, 17(4), 431-447, DOI: 10.1080/13664530.2013.800743

Guskey, T.R. (2003). What makes professional development effective?. Phi Delta Kappan, 84 (10), 748-750.

Ivanova,I., \& Skara-Mincane, R. (2016). Development of professional identity during teachers practice. Procedia-Social and Behavioural Sciences, 232, 529536.

Joseph, D., \& Heading, M. (2010). Putting theory into practice: moving from student identity to teacher identity. Australian Journal of Teacher Education, 35(3), 75- 87.
Kekana, M. \& Gaigher, E. (2018). Understanding Science teachers' classroom practice after completing a professional-development programme: A case study. Eurasia Journal of Math., Sci Tech. 14(8). 1561. doi: https://doi.org/10.29333/ejmste/91831

Lace, I. (2014). Pedagoaiskais pašvartajums topoša skolotaja karejeras attastaba. Promocijas darbs. Liepaja: LiepU

Palmer, A. R. (1998). A proposed nomenclature for stages and series for the Cambrian of Laurentia. canadian Journal of Earth sciences, 35(4), 323-328.

Piedrahíta, A.M.S. (2018). Changing teaching practices: The impact of a professional development program on an English language teacher. Íkala. 23(1). ttp://dx.doi.org/10.17533/udea.ikala.v23n01a08

Rodgers, C. R., \& Scott, K. H. (2008). 40 The development of the personal self and professional identity in learning to teach. Handbook of research on teacher education, 732.

Sparks, P., \& Shepherd, R. (1992). Self-identity and the theory of planned behavior: Assessing the role of identification with "Green Consumerism". Social Psychology Quarterly, 55(4), 388-399.

Stets, J., \& Burke, P. (2000). Identity theory and social identity theory. Social Psychology Quarterly, 63(3), 224-237.

Teaching Council. (2012). Code of Professional Conduct for Teachers. Maynooth: Ireland. Available from http://www.teaching-council.ie/professional standards/code-of- professional-conduct-forteachers. 1425.html (accessed on March 25, 2019)

Tichenor, M.S. \& Tichenor, J.M. (2005). Understanding Teachers' Perspectives on Professionalism. The Professional Educators, 27(1), 89-95.

Van der Klink, M., Kools, Q., Avissar, G., White, S., \& Sakata, T. (2017) Professional development of teacher educators: what do they do? Findings from an explorative international study, Professional Development in Education, 43(2), 163-178, DOI: 10.1080/19415257.2015.1114506

Wayne, A. J., Yoon, K. S., Zhu, P., Cronen, S., \& Garet, M. S. (2008). Experimenting with teacher professional development: Motives and methods. Educational Researcher, 37(8), 469- 479. doi:10.3102/0013189X08327154

Wenger, E. (1998). Communities of practice: Learning, meaning and identity. Cambridge: University Press.

Zaidi, S., Khan, N.R. \& Khan, N. (2018). Organizational factors, teachers' professional development and teaching practices: Findings from Female Elementary School Teachers. International Journal of Experiential Learning \& Case Studies. 3(1). 84-96. 
Conflict of Interest Statement: The authors declare that the research was conducted in the absence of any commercial or financial relationships that could be construed as a potential conflict of interest.

Copyright (C) 2021 Sri Rachmajanti, Gunadi Harry Sulistyo, Fika Megawati and Ayu Alif Nur Maharani Akbar. This is an open-access article distributed under the terms of the Creative Commons Attribution License (CC BY). The use, distribution or reproduction in other forums is permitted, provided the original author(s) and the copyright owner(s) are credited and that the original publication in this journal is cited, in accordance with accepted academic practice. No use, distribution or reproduction is permitted which does not comply with these terms. 